\title{
SEKILAS TENTANG PEMBERIAN GELAR DOKTOR \\ HONORIS CAUSA (HC)/GELAR KEHORMATAN \\ DI UNIVERSITAS GADJAH MADA
}

\author{
Ully Isnaeni Effendi, S.E. ${ }^{l}$
}

Gelar Doktor Honoris Causa (H.C)/Doktor Kehormatan adalah gelar kesarjanaan yang diberikan oleh suatu perguruan tinggi/universitas yang memenuhi syarat kepada seseorang, tanpa orang tersebut perlu untuk mengikuti dan lulus dari pendidikan yang sesuai untuk mendapatkan gelar kesarjanaannya tersebut. Gelar Doktor Honoris Causa dapat diberikan apabila seseorang tersebut telah dianggap berjasa dan atau berkarya luar biasa bagi ilmu pengetahuan dan umat manusia. Tidak semua perguruan tinggi/universitas dapat memberikan gelar Doktor Honoris Causa (H.C)/Doktor Kehormatan, hanya perguruan tinggi/universitas yang memenuhi syaratlah yang diberikan hak secara eksplisit untuk memberi gelar Doktor Honoris Causa (H.C)/Doktor Kehormatan. Terdapat beberapa peraturan yang menjelaskan mengenai pemberian Gelar Doktor Honoris Causa (HC)/Gelar Kehormatan, baik peraturan secara nasional maupun intern Universitas Gadjah Mada(UGM).

\section{Persyaratan}

Pada tahun 1963 terdapat Keputusan Menteri Perguruan Tinggi dan Ilmu Pengetahuan No.120 Tahun 1963 tentang Penertiban Pemberian Gelar "Doctor" dan "Doctor Honoris Causa" (Doktor Kehormatan) serta Gelar-gelar Sarjana Kehormatan Lain. Keputusan Menteri Perguruan Tinggi dan Ilmu Pengetahuan tersebut menyebutkan bahwa:

1. Gelar Doktor, disingkat Dr

Arsiparis Arsip UGM. 
diberikan kepada Sarjana setelah menempuh dengan hasil baik sesuai promosi dengan mempertahankan sebuah thesis.

2. $Y$ a $n g \quad b$ e $r w$ e $n$ a $n g$ menyelenggarakan promosi tersebut adalah universitas negeri/universitas swasta disamakan.

3. Syarat-syarat untuk menjadi promovendus, syarat-syarat dan prosedur promosi diatur Menteri Perguruan Tinggi dan Ilmu Pengetahuan.

Peraturan lainnya adalah Peraturan Pemerintah Republik Indonesia (RI) dengan Nomor 43 Tahun 1980 tentang Pemberian Gelar Doktor Kehormatan (Doctor Honoris Causa). Peraturan Pemerintah RI tersebut dikeluarkan sebagai bentuk penyeragaman pemberian Gelar Doktor Kehormatan (Doctor Honoris Causa) oleh perguruan tinggi dengan berdasarkan syarat-syarat serta tata cara yang seragam dan sesuai dengan makna dan tujuannya. Dalam Peraturan Pemerintah RI tersebut dijelaskan bahwa gelar tersebut adalah gelar kehormatan yang diberikan oleh suatu perguruan tinggi kepada seseorang yang dianggap telah berjasa dan atau berkarya luar biasa bagi ilmu pengetahuan dan umat manusia. Pasal 2 ayat (1) pada Peraturan Pemerintah tersebut menyebutkan bahwa gelar kehormatan ini dapat diberikan kepada Warga Negara Indonesia (WNI) atau Warga Negara Asing (WNA). Pasal 2 ayat (2) menyebutkan bahwa gelar tersebut diberikan sebagai tanda penghormatan bagi jasa atau karya:

a. yang luar biasa di bidang ilmu pengetahuan dan teknologi, pendidikan, dan pengajaran;

b. yang sangat berarti bagi pengembangan pendidikan dan pengajaran dalam satu atau sekelompok bidang ilmu pengetahuan, teknologi, dan sosial budaya;

c. yang sangat bermanfaat bagi kemajuan atau kemakmuran dan kesejahteraan Bangsa dan Negara Indonesia pada khususnya serta umat manusia pada umumnya; 
d.yang secara luar biasa mengembangkan hubungan baik dan bermanfaat antara Bangsa dan Negara Indonesia dengan Bangsa dan Negara lain di bidang politik, ekonomi, dan sosial budaya;

e. ya $\mathrm{ng}$ secara luar biasa menyumbangkan tenaga dan pikiran haoi nerkemhangan

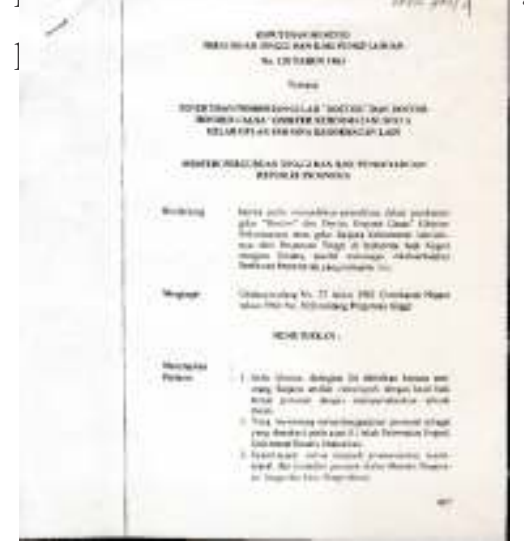

Tidak semua perguruan tinggi/universitas dapat memberikan gelar Doktor Honoris Causa (H.C)/Doktor Kehormatan. Terdapat beberapa persyaratan yang harus dipenuhi oleh perguruan tinggi sebelum memberikan Gelar Doktor Kehormatan (Doctor Honoris Causa), yaitu:
1. pernah menghasilkan sarjana dengan gelar ilmiah doktor;

2. memiliki fakultas atau jurusan yang membina dan mengembangkan bidang ilmu pengetahuan yang bersangkutan dengan bidang ilmu pengetahuan yang menjadi ruang lingkup jasa dan atau karya bagi pemberian gelar;

3. memiliki Guru Besar Tetap sekurang-kurangnya 3 (tiga) orang dalam bidang yang dimaksud dalam hurufb.

Selanjutnya, pada tahun 1992, terdapat Surat Edaran Menteri Pendidikan dan Kebudayaan RI No. 52/MPK/92 tentang Pedoman Pemberian Gelar Doctor Honoris Causa yang menjelaskan beberapa poin yaitu:

1. berdasarkan Undang-Undang No.2 Tahun 1989 tentang Sistem Pendidikan Nasional Pasal 18 ayat (5) yang menyatakan bahwa "institut dan universitas yang memenuhi persyaratan berhak untuk memberikan gelar doktor kehormatan (Doctor Honoris Causa) kepada tokoh-tokoh yang 
dianggap perlu memperoleh penghargaan amat tinggi berkenan dengan jasa-jasa yang luar biasa dalam bidang ilmu pengetahuan, teknologi, kemasyarakatan, dan kebudayaan."

2. Gelar Dr.H.C. dapat diberikan oleh universitas/institut yang memenuhi persyaratan kepada tokoh kesarjanaan/akademisi:

a. yang berjasa luar biasa dalam pengembangan suatu disiplin ilmu tetapi tidak/belum memiliki gelar doktor dalam disiplin yang bersangkutan;

b. yang telah memliki gelar doktor dalam suatu disiplin ilmu yang diperoleh dari suatu universitas/institut, dan bukan dari universitas/institut yang akan memberikan gelar Dr.H.C.

c. yang telah memiliki gelar Dr.H.C. dalam suatu disiplin ilmu, kemudian mendapat gelar Dr.H.C. dalam suatu disiplin i $1 \mathrm{~m} \mathrm{u} \quad \mathrm{a}$ i $\mathrm{n} \quad \mathrm{d}$ a $\mathrm{r}$ i universitas/institut yang sama atau yang lain.

3. Universitas/institut dapat memberikan penghargaan dengan cara lain, seperti misalnya pemberian medali, piagam, penyebutan nama gedung dalam lingkungan almamater, dsb. kepada tokoh dari luar lingkungan kesarjanaan/akademik atas jasanya pada universitas/institut yang bersangkutan atau pengabdiannya untuk kepentingan umum, tetapi tidak dengan pemberian gelar Dr.H.C. yang merupakan gelar akademik.

4. Sekalipun di negara-negara tertentu dilakukan juga pemberian gelar Dr.H.C. kepada tokoh dari $1 \mathrm{i} \mathrm{n} \mathrm{g} \mathrm{k} \mathrm{u} \mathrm{g}$ a $\mathrm{n} \quad 1 \mathrm{u} \mathrm{a} \mathrm{r}$ kesarjanaan/akademik, namun hal itu tidak mendapat apresiasi positif dari kalangan akademik yang ingin mempertahankan bobot gelar Dr.H.C. sesuai dengan harkatnya sebagai gelar akademik. Oleh sebab itu maka sebaiknya di Indonesia dengan tradisi akademik yang relatif masih muda dan memiliki universitas/institut yang belum semuanya mantap dan mapan sebagai pusat ilmiah, sebaiknya 
ditetapkan ketentuan yang ketat sebagaimana tersebut di atas.

Dalam Keputusan Menteri Pendidikan dan Kebudayaan RI No. 036/U/1993 tentang Gelar dan Sebutan Lulusan Perguruan Tinggi sebagai pelaksanaan dari ketentuan Bab VII Peraturan Pemerintah Nomor 30 Tahun 1990 tentang Pendidikan Tinggi disebutkan pada pasal 15 bahwa Gelar Doktor Kehormatan (Doctor Honoris Causa) dapat diberikan kepada seseorang yang telah berjasa luar biasa bagi ilmu pengetahuan, teknologi, kebudayaan, kemasyarakatan dan/atau kemanusiaan. Terdapat persyaratan bagi calon penerima gelar Doktor Kehormatan, yaitu memiliki gelar akademik sekurang-kurangnya sarjana dan berjasa luar biasa dalam pengembangan suatu disiplin ilmu pengetahuan, teknologi, kebudayaan, kemasyarakatan dan/atau kemanusiaan. Pasal 16 ayat (2) menyebutkan bahwa ada persyaratan bagi perguruan tinggi pemberi gelar tersebut adalah universitas atau institut yang memiliki wewenang menyelenggarakan Program Pendidikan Doktor berdasarkan surat keputusan menteri.

Pasal 20 dalam Keputusan Menteri Pendidikan dan Kebudayaan RI No. 036/U/1993 tentang Gelar dan Sebutan Lulusan Perguruan Tinggi disebutkan bahwa perguruan tinggi yang tidak memenuhi persyaratan sesuai dengan ketentuan peraturan perundang-undangan yang berlaku tidak dibenarkan memberikan gelar akademik, sebutan profesional, sebutan profesi dan/atau gelar doktor kehormatan. Ditambahkan pula dalam pasal 21, bahwa:

(1) Gelar akademik dan/atau sebutan profesional yang diperoleh secara sah tidak dapat dicabut atau ditiadakan oleh siapapun;

(2) Keabsahan perolehan gelar akademik dan/atau sebutan profesional dapat ditinjau kembali karena alasan akademik;

(3) Dan pelaksanaan ketentuannya akan diatur oleh Direktur Jenderal. 


\section{Pelaksanaan}

Peraturan Pemerintah RI Nomor 43 Tahun 1980 tentang Pedoman Pemberian Gelar Doktor Kehormatan (Doctor Honoris Causa) menjelaskan bahwa pemberian gelar dapat diusulkan atas saran dan inisiatif perguruan tinggi atau atas saran dan inisiatif pemerintah. Usulan pemberian gelar atas saran dan inisiatif perguruan tinggi diajukan oleh rektor bersangkutan kepada menteri dengan disertai pertimbangan-pertimbangan lengkap atas karya atau jasa yang bersangkutan untuk memperoleh persetujuan menteri. Sedangkan usulan gelar atas saran dan inisiatif instansi pemerintah diajukan oleh menteri yang membawahi bidang tugas instansi pemerintah yang bersangkutan kepada Menteri Pendidikan dan Kebudayaan dengan tembusan kepada perguruan tinggi yang akan memberikan gelar dengan disertai pertimbangan-pertimbangan lengkap atas karya atau jasa yang bersangkutan, untuk memperoleh pertimbangan Menteri Pendidikan dan Kebudayaan.

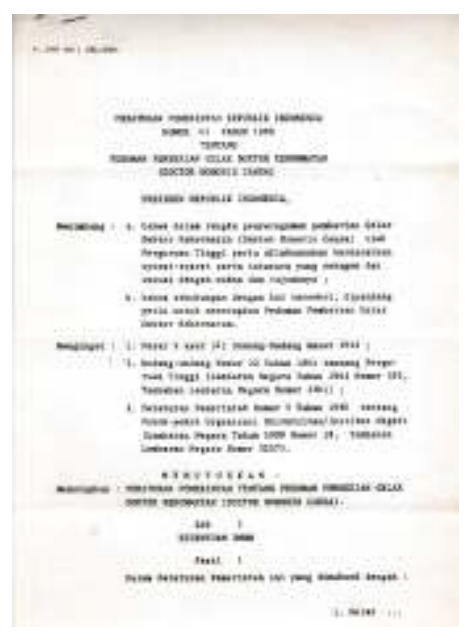

Pemberian gelar atas dasar usulan dari perguruan tinggi harus mendapatkan persetujuan dari Menteri Pendidikan dan Kebudayaan, apabila Menteri Pendidikan dan Kebudayaan tidak menyetujui maka pemberian gelar ini tidak dapat dilaksanakan. Pemberian gelar atas usulan, saran, dan inisiatif dari instansi pemerintah. Apabila perguruan tinggi yang bersangkutan tidak menyetujui, pemberian gelar ini tidak dapat dilangsungkan. Apabila ada usulan atas saran dan inisiatif baik dari instansi pemerintah maupun perguruan tinggi dan kemudian Menteri Pendidikan dan Kebudayaan 
tidak menyetujuinya, pemberian gelar ini tidak dapat dilangsungkan. Apabila terdapat perbedaan pendapat antara Menteri Pendidikan dan Kebudayaan dan menteri yang membawahi atau mengkoordinasikan bidang tugas instansi pemerintah yang bersangkutan mengenai usul pemberian gelar, masalahnya disampaikan kepada Presiden untuk memperoleh keputusannya.

Pada tahun 1992, terdapat Surat Edaran Menteri Pendidikan dan Kebudayaan RI No. 52/MPK/92 tentang Pedoman Pemberian Gelar Doctor Honoris Causa yang menjelaskan bahwa pelaksanaan pemberian gelar Doktor Kehormatan (Doctor Honoris Causa) suatu universitas/institut sebagaimana diatur pasal 8 ayat (5) UndangUndang No. 2 Tahun 1989 tentang Sistem Pendidikan Nasional dan pasal 25 ayat (1) sampai dengan ayat (4) PP No. 30 Tahun 1990 tentang Pendidikan Tinggi perlu memperhatikan kelaziman dan tradisi akademik, sebab gelar Dr.H.C. pada hakikatnya adalah gelar akademik.

Tahun 1993 terbit Keputusan
Menteri Pendidikan dan Kebudayaan RI No. 036/U/1993 tentang Gelar dan Sebutan Lulusan Perguruan Tinggi sebagai pelaksanaan dari ketentuan Bab VII Peraturan Pemerintah Nomor 30 Tahun 1990 tentang Pendidikan Tinggi. Keputusan tersebut mengatur bahwa pemberian gelar Doktor Kehormatan dapat diusulkan oleh senat fakultas dan dikukuhkan senat universitas/institut yang memiliki wewenang. Usul tersebut diajukan oleh rektor kepada menteri dengan disertai pertimbangan lengkap atas karya atau jasa yang bersangkutan, untuk mendapat persetujuan menteri. Usul dan pertimbangan pemberian gelar Doktor Kehormatan tersebut bersifat rahasia. Dan pemberian Gelar Doktor Kehormatan hanya dapat dilakukan apabila mendapat persetujuan menteri dan dilaksanakan sesuai dengan tata cara yang berlaku di universitas/institut yang bersangkutan. Gelar Doktor Kehormatan disingkat menjadi Dr. (H.C.) dan ditempatkan di depan nama penerima hak atas gelar tersebut. 
Doktor Honoris Causa (H.C)/Doktor Kehormatan di UGM

Setiap pemberian gelar

Doktor Kehormatan UGM diikuti dengan keputusan Rektor atau Keputusan Ketua Senat UGM mengenai pelaksanaan pemberian gelar doktor kehormatan. Sebagai contoh adalah pelaksanaan pemberian gelar doktor kehormatan (Doctor Honoris Causa) tahun 1996 yang diatur dalam Keputusan Rektor/Ketua $\mathrm{S}$ e $\mathrm{n} \mathrm{a} \mathrm{t} \quad \mathrm{U} \mathrm{G} \mathrm{M} \quad \mathrm{N}$ o . UGM/161/6000/UM/01/37. Pada Keputusan Rektor/Ketua Senat UGM No. UGM/161/6000/UM/01/37 tentang Pelaksanaan Pemberian Gelar Doktor Kehormatan (Doctor Honoris Causa) pada UGM, tahun 1996, dijelaskan beberapa hal, yaitu:

1. Penilaian usul pemberian gelar doktor kehormatan

a. Usul pemberian gelar doktor kehormatan diajukan atas saran dan inisiatif UGM ataupun atas saran dan inisiatif instansi pemerintah lain, dinilai dan ditetapkan Senat UGM sebagai usul UGM

b. Usul diajukan atas saran dan inisiatif seorang atau lebih staf pengajar fakultas dalam lingkungan UGM diajukan kepada Senat UGM setelah dinilai dan disepakati dengan suara bulat oleh Senat Fakultas yang bersangkutan

c. Dekan selaku Ketua Senat Fakultas mengajukan usul yang telah disepakati kepada Senat UGM dengan dilengkapi pertimbangan kelayakan jasa dan bukti karya akademik untuk ditetapkan menjadi usul UGM

d. Rektor membentuk tim ad hoc yang terdiri atas anggota Senat UGM (apabila perlu ditambah dengan anggota staf pengajar UGM yang bukan Senat UGM)

e. Tim ad hoc bertugas melakukan penilaian pendahuluan atas usul yang diajukan atas saran dan inisiatif instansi pemerintah tersebut

f. Usul yang telah dinilai dan disepakati dengan suara bulat oleh tim ad hoc disertai dengan pertimbangan kelayakan jasa dan bukti karya akademik selengkapnya, diajukan oleh 
Rektor (selaku Ketua Senat) kepada Senat UGM untuk ditetapkan menjadi usul UGM

g. Senat UGM menetapkan usul UGM dengan persetujuan suara bulat yang artinya adalah bahwa anggota Senat yang hadir (yang otoritas bidang ilmu pengetahuannya meliputi jasa dan karya calon penerima gelar tersebut) tidak ada yang mengajukan keberatan asasi

h. Kemudian usul (UGM) tersebut diajukan kepada Menteri Pendidikan dan Kebudayaan untuk memperoleh persetujuan.

2. Peresmian pemberian gelar doktor kehormatan

a. Usul UGM yang mendapat persetujuan dari Menteri Pendidikan dan Kebudayaan diberitahukan oleh Ketua Senat UGM kepada calon penerima gelar Doktor Kehormatan

b. Dibentuk tim promosi oleh Senat UGM yang terdiri dari atas anggota Senat UGM

c. Tim promosi ini bertugas mengumpulkan dan memilih bahan-bahan dokumen yang dapat membuktikan tanpa ragu kelayakan jasa dan keunggulan karya akademik calon penerima gelar Doktor Kehormatan untuk menyusun naskah pidato promosi yang akan dibacakan oleh promotor

d. S e suai tradisi UGM, Ketua Senat UGM bertindak selaku p r o m o t o r d e n g a menyampaikan pidato promosi yang disiapkan final oleh tim promosi

e. Setelah diwisuda, penerima gelar Doktor Kehormatan mengucapkan pidato ilmiah berkenaan dengan ruang lingkup jasa dan karya yang menjadi dasar promosinya.

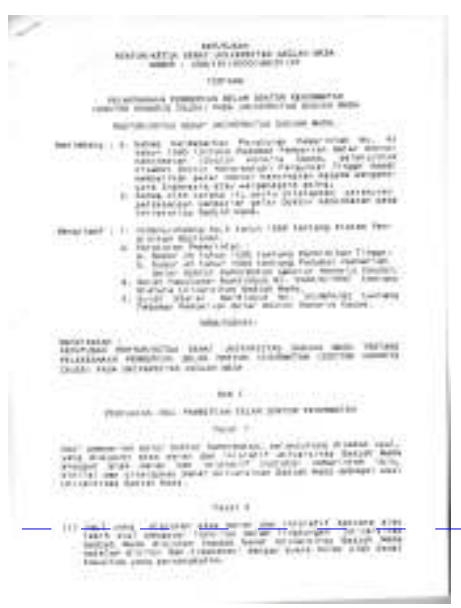


Dalam rangka penilaian usul pemberian gelar doktor kehormatan, usul dari fakultas di lingkungan UGM diajukan kepada Senat UGM, tim seleksi ditetapkan dalam Keputusan Ketua Majelis Guru Besar UGM. Sebagai contoh pada tahun 2002 yaitu Keputusan Ketua Majelis Guru Besar UGM No. 18/SK/MGB/2002 tentang Pembentukan Tim Seleksi Penerima Gelar Doktor Kehormatan (Doctor Honoris Causa) UGM dari Fakultas Ilmu Sosial dan Ilmu Politik UGM dan Keputusan Ketua Majelis Guru Besar UGM No. 19/SK/MGB/2002 tentang Pembentukan Tim Seleksi Penerima Gelar Doktor Kehormatan (Doctor Honoris Causa) UGM dari Fakultas Kedokteran UGM. Keputusan tersebut menetapkan pembentukan tim seleksi penerima Gelar Doktor Kehormatan (Doctor Honoris Causa) UGM dari Fakultas Ilmu Sosial dan Ilmu Politik UGM dan Kedokteran UGM dengan susunan anggota, tugas tim seleksi, dan biaya pelaksanaan kegiatan tugas tim seleksi. Tim seleksi bertugas melakukan penilaian secara selektif serta memutuskan calon penerima Gelar Doktor Kehormatan (Doctor Honoris Causa) UGM dari Fakultas Ilmu Sosial dan Ilmu Politik UGM dan Kedokteran UGM.

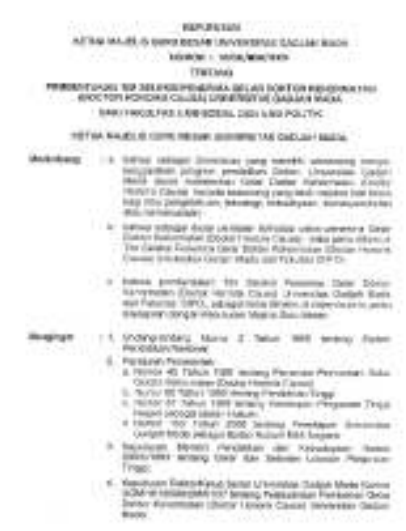

Hal tersebut diatas sesuai dengan Peraturan Pemerintah RI Nomor 43 Tahun 1980 tentang Pemberian Gelar Doktor Kehormatan (Doctor Honoris Causa) yang menjelaskan mengenai pelaksanaan pemberian gelar ini dilakukan oleh perguruan tinggi dengan persetujuan menteri dan sesuai dengan tata cara yang berlaku pada perguruan tinggi yang bersangkutan, lebih lanjut, pemberian gelar ini disertai dengan pemberian piagam yang ditandatangani oleh rektor perguruan 
tinggi serta penerima gelar berhak mencantumkan di depan namanya Gelar Doktor Kehormatan, disingkat dengan Dr.H.C.

\section{Penerima Gelar Doktor Honoris Causa (HC)/Gelar Kehormatan dari UGM}

Sampai dengan saat ini UGM telah memberikan gelar Doktor HC/Doktor Kehormatan kepada presiden, kepala negara, menteri, guru besar, sastrawan, wartawan, dll, baik nasional maupun internasional. Pemberian gelar tersebut sebagai salah satu bentuk apresiasi UGM terhadap sumbangsih penerima gelar terhadap kemajuan ilmu pengetahuan.

Sejak UGM berdiri sampai dengan saat ini, tahun 2016, UGM telah banyak memberikan gelar Doktor HC/Doktor Kehormatan. Di antaranya adalah pada tahun 2016 ini UGM memberikan gelar Doktor HC/Doktor Kehormatan ke-23 kepada Dato' Sri Prof. Dr. Tahir, MBA. atas perhatian dan komitmennya yang tinggi dan berjasa dalam pengembangan pendidikan dan pengajaran dalam satu atau sekelompok bidang ilmu pengetahuan, teknologi dan sosial budaya, kemanusiaan dan kemasyarakatan. Jasa-jasa yang diberikan sangat bermanfaat bagi kemajuan, kemakmuran dan kesejahteraan bangsa dan negara khususnya serta umat manusia pada umumnya. Selain itu, UGM juga pernah memberikan gelar Doktor HC/Doktor Kehormatan ke-4 kepada Bhumibol Adulyedej, Raja Thailand, pada tanggal 12 Februari 1960. Kepada Naradom Sihanoek, Kepala Negara Kamboja, pada tanggal 30 November 1962.

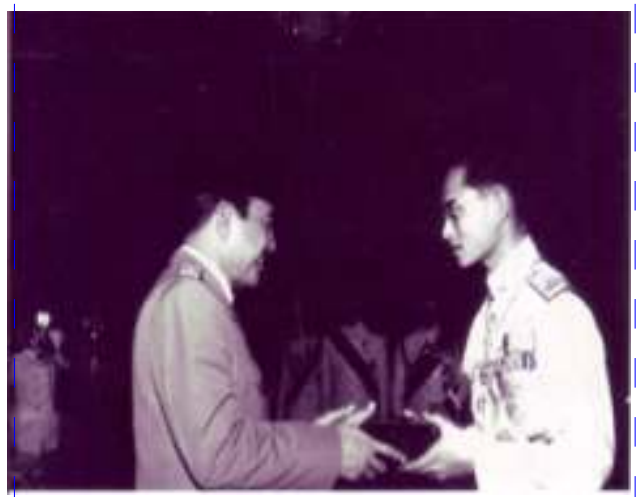

Honoris Causa Bhumibol Adulyadej 


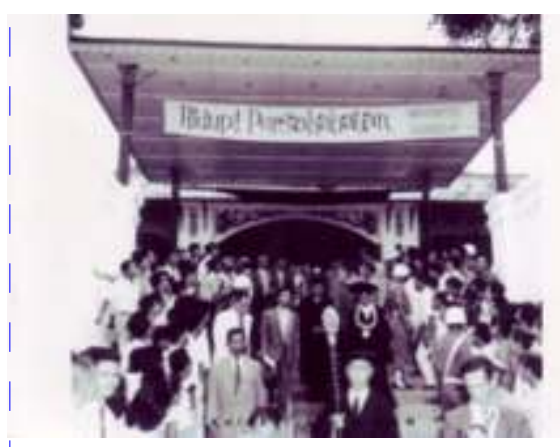

Honoris Causa Norodhom Sihanouk

Diasdado Macapagal, Presiden

Philipina, pada tanggal 24 Februari

1964. Ki Hadjar Dewantoro, Ketua

Perguruan Taman Siswa, pada tanggal

19 Desember 1956. Prof. Ir. H

Johannes, Guru Besar UGM, pada tanggal 19 Agustus 1975. WS Rendra,

\section{SUMBER:}

1. Keputusan Menteri Perguruan Tinggi dan Ilmu Pengetahuan No. 120 Tahun 1963 tentang Penertiban Pemberian Gelar "Doctor" dan Doctor Honoris Causa" (Doktor Kehormatan) serta Gelar-Gelar Sarjana Kehormatan Lain (SA/SC.PM/4)

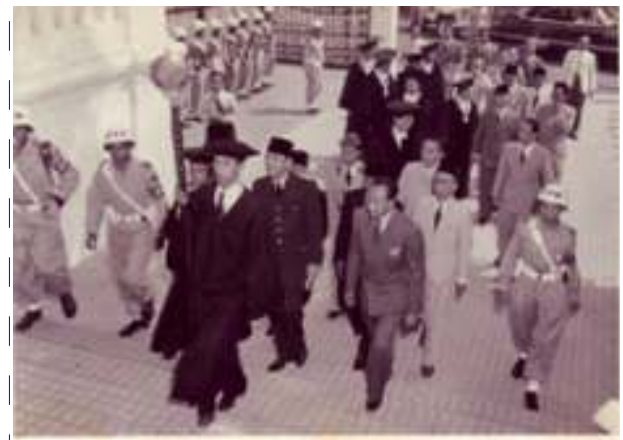

Honoris Causa Ir. Soekarno

Penyair/Budayawan, pada tanggal 24 Agustus 2008. Momentum pemberian gelar Doktor HC/Doktor Kehormatan yang pertama kali diberikan oleh UGM adalah kepada Ir. Soekarno, Presiden Republik Indonesia, pada tanggal 19 Desember 1951 pada bidang hukum.

2. Surat Edaran Menteri Pendidikan dan Kebudayaan RI No. 52/MPK/92 tentang Pedoman Pemberian Gelar Doctor Honoris Causa (SA/SC.PM/44)

3. Peraturan Pemerintah RI No. 43 Tahun 1980 tentang Pedoman Pemberian Gelar Doktor Kehormatan (Doctor Honoris 
Causa) (SA/SC.PM/17)

4. Keputusan Rektor/Ketua Senat Universitas Gadjah Mada No. $\mathrm{UGM} / 161 / 6000 / \mathrm{UM} / 01 / 37$ tentang Pelaksanaan Pemberian Gelar Doktor Kehormatan (Doctor Honoris Causa) pada Universitas Gadjah Mada (AS2/PP.PH/18)

5. Keputusan Menteri Pendidikan dan Kebudayaan RI No. 036/U/1993 tentang Gelar dan Sebutan Lulusan Perguruan Tinggi

6. Keputusan Ketua Majelis Guru Besar UGM No. 18/SK/MGB/2002 tentang Pembentukan Tim Seleksi Penerima Gelar Doktor Kehormatan (Doctor Honoris Causa) UGM dari Fakultas Ilmu
Sosial dan Ilmu Politik

7. Keputusan Ketua Majelis Guru Besar UGM No. 19/SK/MGB/2002 tentang Pembentukan Tim Seleksi Penerima Gelar Doktor Kehormatan (Doctor Honoris Causa) UGM dari Fakultas Kedokteran.

8. Daftar Nama Penerima Derajat Doktor HC UGM (SA/PP.PH/1)

9. Honoris Causa Ir. Soekarno (AF/AM.MC/1951-1F)

10.Honoris Causa Norodhom Sihanouk (AF/AM.MC/1962-1F)

11.Honoris Causa Bhumibol Adulyadej (AF2/AM.MC/19601A) 